Dostupné z: http://www.ped.muni.cz/capv2011/sbornikprispevku/lukasova.pdf

\title{
Výzkum pojetí kvality života dětí u žáků v pátých třídách
}

\author{
Research conception of children's life quality of pupils in five's classes pupils
}

\author{
Hana Lukášová
}

\begin{abstract}
Abstrakt: V této stati se budeme věnovat výsledkům výzkumu GAČR (výzkumný projekt č. 406/06/0035) s názvem Kvalita života u dětí a dospívajicich, který byl řešen pod vedením J. Mareše $\left(2006-2008^{1}\right)$ z lékařské fakulty Univerzity Karlovy v Hradci králové. V příspěvku jsou sledovány následující cíle: 1) vymezení významu pojmu kvalita života dětí, 2) stanovení otázek empirického výzkumu, 3) popis procesu výzkumu, vzorku a metody, 4) přehled vybraných výsledků výzkumu a jejich interpretace.
\end{abstract}

Klíčová slova: kvalita života, prekoncept, žák, subjektivního žákovské pojetí kvality života dětí

Abstract: The study has been conducted within the Research project no. 406/06/0035 - "Life Quality of Children and Adolescents" managed by Prof. PhDr. Jiří Mareš, CSc. from the Faculty of Medicine of the Charles University in Hradec Králové (2006-2008). In the paper there are next five aims: 1) the conception of the quality of the children's life, 2) the formulation of question for empirical research, 3) the description of the process research, 4) the view of the results and their interpretation.

Keywords: life quality, preconception, pupil, the subjective preconception of the children's life quality.

\section{1 Úvodem}

Náš empirický výzkum se zaměřil na žáky v pátých třídách. Jde o první pokus zjistit, ke kterým oblastem kvality života se hlásí žáci sami, když jim poskytneme prostor ke psaní vlastních názorů.

\section{Pojetí pojmu kvalita života dětí a vybrané výsledky jeho výzkumu}

Pojmové spojení kvalita (lidského) života bylo podrobně rozebráno v přehledové studii J. Mareše (2006, s. 11-28). Mareš zmapoval problémy s pojetím pojmu a s jeho definováním v zahraničí i u nás. Ve studii najdeme řadu obecných modelů, hierarchických a strukturálně dynamických př́stupů k pojetí kvality života dětí. Multidimenzionální pojem kvalita života, který byl východiskem výzkumu, byl formulován světovou zdravotnickou organizací: „Jde o

\footnotetext{
${ }^{1}$ Poděkování prof. PhDr. Jiřímu Marešovi, CSc. za poskytnutí příležitosti pracovat v jeho výzkumném týmu GAČR.
} 
individuální percipování své pozice v̌̌ivotě, v kontextu té kultury a toho systému hodnot, $v$ nichž jedinec žije; vyjadřuje jedincův vztah k jeho vlastním cílům, očekávaným hodnotám a zájmům..., zahrnuje komplexním způsobem jedincovo somatické zdraví, psychický stav, úroveň nezávislosti na okolí, sociální vztahy, jedincovo presvědčení, víru - a to vše ve vztahu k hlavním charakteristikám prostředí...Kvalita života vyjadřuje subjektivni hodnocení, které se odehrává v určitém kulturním, sociálním a environmentálním kontextu." (J. Mareš, 2006, s. 25). Empirickému výzkumu kvality života dětí byly doposud věnovány studie $z$ oblasti medicíny. Vymezení pojmu není ustáleno v žádné vědní oblasti. V našem výzkumu jsme neměli za cíl ustálit pojem kvalitu života dětí. Zajímal nás subjektivní prekoncept tohoto pojmu u žáků pátých tříd.

\section{Problém empirického výzkumu}

Výzkum oblastí kvality života dětí navazuje na první empirické výsledky, které byly dříve zjišt’ovány prostřednictvím dotazníků, o nichž Mareš konstatoval, že „Překvapuje, jak málo pozornosti věnuji dotazniky učení a poznáváni" "(2008, s. 121). U studentů učitelství bylo 15\% prekoncepů kvality života dětí vztaženo ke vzdělávání a ke škole (Lukášová, 2008, s. 162, 2009, s. 125). Výzkum ukázal, že studenti učitelství vidí vnitřní vztah mezi jejich pojetím kvality života dětí a učitelským jednáním v pedagogických situacích výchovy a výuky (96\% studentů - viz Lukášová, 2008, s. 170). Další přehled empirických výzkumů najdeme ve studiích Svatoše a Švarcové (2006, s. 173, 2007, s. 160, 2008, s. 136), které popisují kvalitativní i kvantitativní výzkumy indikátorů kvality života dětí v roli žáků základní školy. Studie Hajer-Mülerové a kolektivu přibližuje aplikaci španělského výzkumu v našich podmínkách (2006, s. 159). Naším problémem bylo zjistit, jaké je subjektivní pojetí kvality života dětí u žáki v pátých třidách základni školy. Výzkum probíhal ve spolupráci diplomantkou M. Švikruhovou (2009).

\section{Metoda a vzorek výzkumu}

Byl použit podnět k polostrukturovanému psaní názorů žáků J. Mareše (2006). Náměty ke zjištování obsahu pojmu ,kvalita života u děti" se skládaly se ze tř́i úkolů, na které měli žáci pátých tříd anonymně odpovědět:

- Úkol 1: Když uvidíš někde v časopise titulek Kvalita života u dětí, co všechno si pod tímto označením představíš ty sám, když se trochu zamyslíšs?

- Úkol 2: Jak bys vyložil mladšímu kamarádovi titulek Kvalita života u dětí, aby tomu opravdu porozuměl?

- Úkol 3: Máme připravenu jednu tabulku, kterou je třeba doplnit. Představ si v duchu své spolužáky, kamarády, známé děti a dopiš do tabulky tři př́klady. Nechceme žádná jména, jen vystižení zvláštností jejich života. Popis toho, proč si myslíš, že mají špatný, normální nebo výborný život.

Dotazníkové šetření i strukturované rozhovory prováděla M. Švikruhová v listopadu a prosinci 2007 v Orlové (viz tab. 2-5). Do jejího zpracování byly použity i dotazníky z Ostravy (viz tabulka 1), které zpracovala A. Saparová (2007). Celkové výsledky byly zpracovány od 174 žáků pátých tříd, jejichž věk byl mezi desátým a dvanáctým rokem. 
Tabulka 1

Popis výzkumného souboru

\begin{tabular}{|l|l|l|l|l|l|l|l|l|}
\hline \multicolumn{7}{|c|}{ ŽÁCI Z OSTRAVY (82) A ORLOVÉ (92) } \\
\hline Věk & 10 & 11 & 12 & \multicolumn{2}{|l|}{ Žáků celkem } \\
\hline Pohlaví & Ch & D & Ch & D & Ch & D & \\
\hline A & 10 & 22 & 49 & 65 & 16 & 12 & $\mathbf{1 7 4}$ \\
\hline
\end{tabular}

\section{Vybrané výsledky výzkumu}

Tabulka 2

Pořadí četnosti výroků v odpovědi k úkolu č. 1: Když uvidiš někde v časopise titulek „Kvalita života děti" “, co všechno si pod tímhle označením predstaviš ty sám, když se trochu zamysliš? (Švikruhová, 2009, s. 67).

\begin{tabular}{|l|l|l|l|}
\hline & Pořadi kategorií výroků k pojetí kvality & Absolutní & Relativní \\
\hline 1. & Psychická stránka - štěstí, spokojenost & 51 & 15 \\
\hline 2. & Rodina & 50 & 14 \\
\hline $\mathbf{3 .}$ & Prostředí - podmínky & 43 & 12 \\
\hline $4 .-5$. & Materiální stránky života & 39 & 11 \\
\hline $4 .-5$. & Potř́by dětí & 37 & 11 \\
\hline $6 .-7$. & Přátelé & 33 & 9 \\
\hline $6 .-7$. & Zdraví & 32 & 9 \\
\hline $8 .-9$. & Vy̌̌śí hodnoty života & 25 & 7 \\
\hline $8 .-9$. & Výchova & 23 & $\mathbf{7}$ \\
\hline 10. & Vzdělání - škola & 18 & $\mathbf{5}$ \\
\hline & Celkem & $\mathbf{3 5 1}$ & $\mathbf{1 0 0} \%$ \\
\hline
\end{tabular}

Př́iklady odpovědí při zpracování úkolů č. 2: Jak bys vyložil mladšímu kamarádovi titulek Kvalita života u dětí, aby tomu opravdu porozuměl? (D v závorce znamená - dívka, CH chlapec)

Opis zadání:

"Někdo z dětí má třeba špatný život, normální nebo výborný." (11, D)

"Člověk může mít špatný, normální nebo výborný život." (11, D)

Přiléhavá odpověd’ - jednoduchá, velmi stručná:

"Život." (10, D)

"Máš rodinu a peníze." (11, Ch)

" Že se má super." (10, D)

Popis několika prvků, které souvisí s kvalitou života:

některé odpovědi zdůrazňují, že vše nemusí být skvělé

"Budou se o tebe starat, budeš mít to, co chceš, ale vždy to nemusí být skvělé, je tam mnoho protikladi." (10, D) 
"Že mají co si prejeí a mají rodiče." (11, Ch)

Uvádění protikladů:

"Kvalita života u dětí je odlišná, jedni se maji lépe a druzi hůr̆." (11, Ch)

"Třeba, je někdo rozmazlený a někdo v Africe má hlad." (11, D)

" Jak se děti mají, jestli dobře nebo špatně." (12, Ch)

Vidění pozitivního:

"Mit hodné rodiče, chodit na dobrou školu, hezké oblečení, hodně kamarádů, mit jednou za čas to, co si přeji." (12, D)

"Mit právo na svi̊j názor, starat se o nějaké zvirre, aby bylo dítě štastné." (12, Ch)

Moralizace:

"Musí být zdravý, nesmi být týrán, nesmí pít alkohol a kouřit." (11, Ch)

"Musiš poslouchat, dobře oblékat, že se nesmiš vzdávat a dojit k cili" (11, D)

Použití přirovnání, dramatizace:

"Když je roztrhaná panenka, tak je k nepoužiti" $(11, \mathrm{D})$

"Ukázala bych mu to tak, že bych předstírala, že jsem namyšlená, tak aby to pochopil." (11, D)

"Mému bratrovi bych řekla, že je to, jako by byl celý život někdy zavřený, že to je hrozné." $(10, \mathrm{D})$

Uvedení osobního př́íkladu:

"Představím si, kdyžjsem venku s kamarády a s křečkem a smějeme se." (11, Ch)

"Mám rodinu, mám domov, mám hračky a co jíst." (11, Ch)

"Mamka, tatka, bratr, mám si kde hrát." (10, D)

Uvedení konkrétního př́íkladu ze života druhých dětí:

"Některé děti se narodí postižené a budou stejně žit normálně." (11, Ch)

"Že ty děti mají své rodiče, nejsou v dětských ústavech a domovech, jsou zdraví a bez nemoci." (11, D)

"Povídala by jsem mu o tom, jak žijí děti." (11, D)

Vysvětlení pojmu kvalita života:

"Jak se to dítě má, jaké má kamarády a rodiče, jaké má prostředí pro život." (12, Ch)

" Jak je dítě vychováváno, jakou dostává stravu, v jakém prostředi žije." (12, D)

"Mamka a tatík, sourozenci, kteři tě mají rádi a věnuji ti volný čas a lásku, základní věci životu, rodina." (11, D) 
Tabulka 3

Pořadí četnosti výroki̊ jak popisují žáci špatný život (Švikruhová, 2009, s. 80)

\begin{tabular}{|l|l|l|l|}
\hline & Por̆adí kategorií, které děti preferují & Absolutní & Relativní \\
\hline $\mathbf{1 .}$ & Rodiče a rodina & 246 & 44 \\
\hline $\mathbf{2 .}$ & Materiální zázemí & 70 & 13 \\
\hline $\mathbf{3 .}$ & Vztah s okolím & 65 & 12 \\
\hline 4. & Škola & 44 & $\mathbf{8}$ \\
\hline 5. & Volnost & 33 & 6 \\
\hline 6. & Vlastnosti a chování & 27 & 5 \\
\hline 7. & Zdraví & 25 & 4 \\
\hline 8. & Pocity a naladění & 20 & 4 \\
\hline 9. & Zájmy & 13 & 2 \\
\hline $10 .-11$. & Návykové látky & 6 & 1 \\
\hline $10 .-11$. & Hygiena & 6 & 1 \\
\hline & Celkem & $\mathbf{5 5 5}$ & $\mathbf{1 0 0} \%$ \\
\hline
\end{tabular}

Tabulka 4

Pořadí četnosti výroki jak popisuji žáci normální život (Švikruhová, 2009, s. 87)

\begin{tabular}{|l|l|l|l|}
\hline & Pořadi kategorií které děti preferují & $\begin{array}{l}\text { Absolutní } \\
\text { četnost }\end{array}$ & $\begin{array}{l}\text { Relativní } \\
\text { četnost }\end{array}$ \\
\hline $\mathbf{1 .}$ & Rodiče a rodina & 151 & 30 \\
\hline $\mathbf{2 .}$ & Materiální zázemí & 143 & 28 \\
\hline $\mathbf{3 .}$ & Vztah s okolím & 64 & 12 \\
\hline 4. & Škola & 49 & $\mathbf{1 0}$ \\
\hline 5. & Volnost & 32 & 6 \\
\hline 6. & Pocity a naladění & 28 & 6 \\
\hline 7. & Zájmy & 18 & 3 \\
\hline 8. & Vlastnosti a chování & 11 & 2 \\
\hline 9. & Zdraví & 10 & 2 \\
\hline 10. & Návykové látky & 3 & 1 \\
\hline & Celkem & $\mathbf{5 0 9}$ & $\mathbf{1 0 0} \%$ \\
\hline
\end{tabular}

Tabulka 5

Pořadí četnosti výroků jak popisuji žáci výbornýživot (Švikruhová, 2009, s. 94)

\begin{tabular}{|l|l|l|l|}
\hline & Pořadi kategorií, které děti preferuji & $\begin{array}{l}\text { Absolutni } \\
\text { četnost }\end{array}$ & $\begin{array}{l}\text { Relativní } \\
\text { četnost }\end{array}$ \\
\hline $\mathbf{1 .}$ & Materiální zázemí & 196 & 33 \\
\hline $\mathbf{2 .}$ & Rodiče a rodina & 147 & 24 \\
\hline $\mathbf{3 .}$ & Vztah s okolím & 66 & 11 \\
\hline 4. & Vlastnosti a chování & 47 & 8 \\
\hline $5 .-6$. & Volnost & 37 & 6 \\
\hline $5 .-6$. & Pocity a naladění & 37 & 6 \\
\hline 7. & Škola & 34 & $\mathbf{6}$ \\
\hline $8 .-9$. & Zájmy & 17 & 3 \\
\hline $8 .-9$. & Zdraví & 17 & 3 \\
\hline & Celkem & $\mathbf{5 9 8}$ & $\mathbf{1 0 0} \%$ \\
\hline
\end{tabular}




\section{Interpretace výsledků a závěr}

Výzkum ověřil, že lze použít výzkumnou metodu polostrukturovaného psaní názorů u žáků pátých tř́́d. Žáci v pátých trrídách jsou schopni svými slovy vyjádřit své subjektivní pojetí kvality života dětí. Jejich pojetí lze tř́dit do následných kategorií. V jejich rámci lze identifikovat i názory, které se nějak propojují se souvislostí školy, výuky a výchovy. V charakteristice špatné kvality života dětí se škola ocitla na čtvrtém místě v četnosti $(8 \%$ názorů žáků) a v charakteristice normální kvality života dětí taktéž na čtvrtém místě (10\% názorů žáků). V př́padě výborné kvality života byla charakteristika spojená se školou až na sedmém místě ( $6 \%$ názorů žáků pátých tříd).

\section{Literatura}

Hajer-Mülerová, L., Škoda, J., Procházková, Z., \& Doulík, P. (2006). Hodnocení kvality života zdravých žáků (inspirace španělským výzkumem). In J. Mareš (Ed.), Kvalita života u dětí a dospivajicich. I. (pp. 159-167). Brno: MSD,

Lukášová, H. (2006). Pojetí kvality života dětí a učitelské znalosti. In J. Mareš (Ed.), Kvalita života u dětí a dospivajícich. I. (pp. 69-80). Brno: MSD.

Lukášová, H. (2007). Prekoncept pojmu kvalita života dětí u studentů učitelství. In J. Mareš (Ed.), Kvalita života dětí a dospivajících II. (pp. 179-189). Brno: MSD.

Lukášová, H. (2008). Pojetí kvality života dětí u studentů učitelství. In J. Mareš (Ed.), Kvalita života dětí a dospivajícich III. (pp. 159-172). Brno: MSD.

Lukášová, H. (2007). Kvalita života dětí - prekoncept studentů učitelství. B. Koukola \& J. Mareš (Eds.), Psychologie zdraví a kvalita života (pp. 110-115). Brno: MSD.

Lukášová-Kantorková, H. (2006). Kvalita života dítěte ve škole a př́íprava učitelů. In G. Kapica (Ed.), Wspólczesne konteksty dzieciństwa (pp. 45-55). Racibórz: Państwowa Wyzsza Szkola Zawodowa.

Lukášová, H. (2009). Student's preconception of children's life quality. The New Educational Review, $17(1), 125-134$.

Mareš, J. (Ed.). (2006). Kvalita života u dětí a dospivajicích I. Brno: MSD.

Mareš, J. (Ed.). (2007). Kvalita života u dětí a dospivajicich II. Brno: MSD.

Mareš, J., \& Koukola, J. (Eds.). (2007). Psychologie zdraví a kvalita života. Brno: MSD.

Mareš, J., \& Marešová, J. (2007) Kvalitativní metody pro zjišt’ování kvality života u dětí. In J. Mareš \& J. Koukola (Eds.), Psychologie zdravi a kvalita života (pp. 104-109). Brno: MSD.

Mareš, J. et al. (2008). Kvalita života dětí a dospivajicich III. Brno: MSD.

Mareš, J. (2009). Edukace založená na důkazech: inspirace pro pedagogický výzkum i školní praxi. Pedagogika, 59(3), 232-258.

Mareš, J. (2010). Kvalita života žáků a škola. Pedadogika SK, (1), 47-72.

Saparová, A. (2007). Výuka v primárním vzdělávání z hlediska proživání žáka. (Diplomová práce). Ostrava: PdF OU v Ostravě.

Svatoš, T., \& Švarcová, E. (2006). Indikátory kvality života žáků základní školy. In J. Mareš (Ed.), Kvalita života u détí a dospívajicich I. (pp.171-182). Brno: MSD.

Svatoš, T., \& Švarcová, E. (2007). Zkoumání kvality života žáků ZŠ v podmínkách ohniskové skupiny. In J. Mareš (Ed.), Kvalita života dětí a dospivajicich II. (pp. 159-178). Brno: MSD.

Svatoš, T., \& Švarcová, E. (2008). Kvalita života pohledem žáků základní školy. In J. Mareš (Ed.), Kvalita života dětí a dospivajicich III. (pp. 135-157). Brno: MSD.

Švikruhová, M. (2009). Kvalita života dětí v prekonceptech žákủ. (Diplomová práce). Ostrava: PdF OU V Ostravě. 


\section{Kontakt}

Prof. PhDr. Hana Lukášová, CSc.

Ostravská Univerzita

Pedagogická fakulta, Katedra pedagogiky primárního a alternativního vzdělávání Mlýnská 5, 70100 Ostrava

e-mail: hana.lukasova@osu.cz

\section{Bibliografické údaje}

Lukášová, H. (2011). Výzkum pojetí kvality života dětí u žáků v pátých tř́́dách. In T. Janík, P. Knecht, \& S. Šebestová (Eds.), Smišsený design v pedagogickém výzkumu: Sborník přispěvků z 19. výročni konference České asociace pedagogického výzkumu (s. 118-124). Brno: Masarykova univerzita.

Dostupné z: http://www.ped.muni.cz/capv2011/sbornikprispevku/lukasova.pdf doi: 10.5817/PdF.P210-CAPV-2012-34 